\title{
Sporadic Alzheimer's Disease Begins as Episodes of Brain Ischemia and Ischemically Dysregulated Alzheimer's Disease Genes
}

\author{
Ryszard Pluta - Mirosław Jabłoński • \\ Marzena Ulamek-Koziol • Janusz Kocki • \\ Judyta Brzozowska • Sławomir Januszewski • \\ Wanda Furmaga-Jabłońska • Anna Bogucka-Kocka • \\ Ryszard Maciejewski • Stanisław J. Czuczwar
}

Received: 2 February 2013 / Accepted: 5 March 2013 /Published online: 22 March 2013

(C) The Author(s) 2013. This article is published with open access at Springerlink.com

\begin{abstract}
The study of sporadic Alzheimer's disease etiology, now more than ever, needs an infusion of new concepts. Despite ongoing interest in Alzheimer's disease, the basis of this entity is not yet clear. At present, the bestestablished and accepted "culprit" in Alzheimer's disease pathology by most scientists is the amyloid, as the main molecular factor responsible for neurodegeneration in this disease. Abnormal upregulation of amyloid production or a disturbed clearance mechanism may lead to pathological accumulation of amyloid in brain according to the "amyloid
\end{abstract}

R. Pluta $(\bowtie) \cdot$ M. Ułamek-Kozioł $\cdot$ S. Januszewski

Laboratory of Ischemic and Neurodegenerative Brain Research,

Mossakowski Medical Research Centre, Polish Academy of

Sciences, Pawińskiego 5 Str.,

02-106 Warsaw, Poland

e-mail: pluta@cmdik.pan.pl

M. Jabłoński

Department of Orthopaedics and Rehabilitation,

Medical University of Lublin, Jaczewskiego 8 Str.,

20-954 Lublin, Poland

J. Kocki

Department of Clinical Genetics, Medical University of Lublin,

Radziwillowska 11 Str.,

20-081 Lublin, Poland

J. Brzozowska

Department of Clinical Psychology, Medical University of Lublin, Chodzki 6,

20-093 Lublin, Poland

W. Furmaga-Jabłońska

Department of Neonate and Infant Pathology, Medical University of Lublin, Chodzki 2 Str.,

20-093 Lublin, Poland hypothesis." We will critically review these observations and highlight inconsistencies between the predictions of the "amyloid hypothesis" and the published data. There is still controversy over the role of amyloid in the pathological process. A question arises whether amyloid is responsible for the neurodegeneration or if it accumulates because of the neurodegeneration. Recent evidence suggests that the pathophysiology and neuropathology of Alzheimer's disease comprises more than amyloid accumulation, tau protein pathology and finally brain atrophy with dementia. Nowadays, a handful

A. Bogucka-Kocka

Department of Pharmaceutical Botany, Medical

University of Lublin, Chodzki 1 Str.,

20-093 Lublin, Poland

R. Maciejewski

Department of Human Anatomy, Medical University of Lublin,

Jaczewskiego 4 Str.,

20-090 Lublin, Poland

\section{S. J. Czuczwar}

Department of Pathophysiology, Medical University of Lublin, Jaczewskiego 8 Str.,

20-954 Lublin, Poland

\section{S. J. Czuczwar}

Department of Physiopathology, Institute of Rural Health,

Jaczewskiego 2 Str.,

20-950 Lublin, Poland 
of researchers share a newly emerged view that the ischemic episodes of brain best describe the pathogenic cascade, which eventually leads to neuronal loss, especially in hippocampus, with amyloid accumulation, tau protein pathology and irreversible dementia of Alzheimer type. The most persuasive evidences come from investigations of ischemically damaged brains of patients and from experimental ischemic brain studies that mimic Alzheimer-type dementia. This review attempts to depict what we know and do not know about the triggering factor of the Alzheimer's disease, focusing on the possibility that the initial pathological trigger involves ischemic episodes and ischemia-induced gene dysregulation. The resulting brain ischemia dysregulates additionally expression of amyloid precursor protein and amyloid-processing enzyme genes that, in addition, ultimately compromise brain functions, leading over time to the complex alterations that characterize advanced sporadic Alzheimer's disease. The identification of the genes involved in Alzheimer's disease induced by ischemia will enable to further define the events leading to sporadic Alzheimer's disease-related abnormalities. Additionally, knowledge gained from the above investigations should facilitate the elaboration of the effective treatment and/or prevention of Alzheimer's disease.

Keywords Brain ischemia $\cdot$ Blood-brain barrier $\cdot$ Neuronal death - Dementia · Alzheimer's disease · Genes · Amyloid precursor protein $\cdot$ Presenilins $\cdot$ Apolipoproteins $\cdot$ Secretases

\section{Introduction}

Ischemic brain injury in animals causes progressive and irreversible cognitive impairment with Alzheimer's phenotype, dysfunction of new information learning in the shortterm survival postischemia, and memory loss in the longterm survival postischemia, suggesting that those deficits are due to impairment of memory retention or the memory recall process [1-3]. Also, the progressive damage in the hippocampus [4-7] and the white matter [5, 8,9] were found, following brain ischemia. Transient brain ischemia resulted in an insidious delayed death of specific vulnerable pyramidal neurons within the CA1 subfield of the hippocampus, associated with inflammation [4-6, 10]. Rarefaction of white matter was noted a few months following ischemia and markedly increased 1 year after ischemic brain injury $[5,8,9]$. White matter changes are characteristic for elderly persons and individuals with cognitive impairment. The above changes also appear in sporadic Alzheimer's disease patients, suggesting that brain ischemia can be regarded as a useful model for understanding mechanisms responsible for the development of dementia.

The detection of $\beta$-amyloid peptide, presenilins, apolipoproteins, $\alpha$-synuclein and hyperphosphorylated tau protein immunoreactivity in animal ischemic brains [11-15], in patient brains after episodes of ischemia [16-20] and occurrence of these proteins in Alzheimer's disease brains have suggested common molecular mechanisms of neuronal death, pathological proteins accumulation and dementia in both brain ischemia and Alzheimer's diseases. It is of interest to notice that in 1911 Alois Alzheimer wrote "...the plaques are not the cause of senile dementia, but only an accompanying feature of senile involution of the central nervous system" [21], implying that some other features and pathology were involved in the dementia, as suggested now by a handful of scientists [13, 22-31].

Brain ischemia and Alzheimer's disease are the most common degenerative diseases of the human central nervous system [32, 33]. Alzheimer's disease has a very insidious onset: we do not know precisely when neuronal dysfunction begins [34]. Both illnesses affect multiple neuronal systems and involve abnormal aggregation and deposition of potentially dangerous proteins in selected neuronal types. In both disorders the vulnerability of specific neuron groups is reflected in a characteristic topographical distribution pattern of the lesions throughout the brain cortex and hippocampus, which remains remarkably consistent across cases. The brains of patients dying with Alzheimer's disease are devastated by widespread neuron loss, amyloid plaques and tangles [33].

Although memory loss is a key symptom of Alzheimer's disease [35], pathological processes leading to cognitive deficits are poorly understood and exact molecular mechanisms underlying dementia remain to be elucidated [34]. It is difficult to address this problem in human studies and impossible in cultured neurons. Therefore, animal models are needed to elucidate the molecular mechanisms leading to dementia $[3,4,26]$. Now, Alzheimer's disease and a number of other neurodegenerative diseases are known to result from the aggregation of proteins that misfold and accumulate as fibrillar amyloid deposits in selectively vulnerable areas of the central nervous system where they are thought to compromise the function and viability of neurons and glia. The above-mentioned changes are typical hallmarks of Alzheimer's disease pathology [33].

In consequence, further experimental studies to clarify the triggering effect of brain ischemia on sporadic Alzheimer's disease development will not only lead to reevaluation of the neuropathogenesis of Alzheimer's disease but may provide key data for the prevention and therapy of Alzheimer's disease as well [36]. Altogether, it is hypothesized that the brain ischemia could be the main cause of sporadic Alzheimer's disease [22, 23, 25, 27, 28, $37,38]$. Therefore, it is of consequence to study the effects of ischemic brain episodes on Alzheimer's disease formation through animal model(s) in order to understand the neuropathogenesis of sporadic Alzheimer's disease [3, 4 , 
26]. In the face of new interesting findings, in this review we will try to put all this information together from a genetic point of view. It is hoped that new findings will give us some insight into the complex interaction between ischemic signaling to Alzheimer-associated genes and $\beta$-amyloid peptide generation in progressing injury of the ischemic brain to dementia with Alzheimer's phenotype.

In this paper, we review the hard-earned data presenting ischemic induction of amyloid precursor protein, presenilins, apolipoproteins and secretase genes, which play key roles in $\beta$-amyloid peptide generation. However, it is of interest that following brain ischemia in humans, increased both $\beta$ amyloid peptide and tau protein levels were noted in blood [39-41]. The presented data will strongly underpin hypothesis that brain ischemia is involved in the etiology of sporadic Alzheimer's disease. Potential contribution and impact of ischemically activated genes on sporadic Alzheimer's disease development remain to be established at both the genetic and functional levels.

\section{Induction of Alzheimer-Related Genes Following Experimental Brain Ischemia}

\section{Amyloid Precursor Protein}

The gene coding for amyloid precursor protein has been identified on chromosome 21. Following transient focal ischemic brain episode, amyloid precursor protein mRNA had increased by $200 \%$ in the penumbra and $150 \%$ in core on the seventh day after injury. The postischemic data suggest that ischemia influences amyloid precursor protein mRNA expression, which may contribute directly or indirectly to the deterioration of cognitive deficits in the postischemic period [42, 43]. Following ischemia, only the Kunitz protease inhibitor bearing isoform was increased. The above study shows that ischemia alters Kunitz protease inhibitor amyloid precursor protein/amyloid precursor protein 695 ratios in brain and this shift in precursor isoforms could be linked to degeneration and activation of astrocytes in the postischemic period [44]. In persistent focal ischemic brain injury, amyloid precursor protein mRNA species, which contain a Kunitz-type protease inhibitor domain, were induced in the cortex by day 21 of postischemia but the total amount of precursor mRNA did not change. This study suggests a selective role of amyloid precursor protein species that contain the Kunitz protease inhibitor domain in molecular mechanisms of postischemic brain injury [45]. As a result of experimental brain ischemia, amyloid precursor protein 770 and amyloid precursor protein 751 mRNAs were expressed during 7 days postischemia [46]. Amyloid precursor protein mRNA was investigated in ovariectomized rats $1 \mathrm{~h}$ and 1 day postischemia. At $1 \mathrm{~h}$ postischemia, the animals expressed a significant increase in amyloid precursor protein mRNA in the affected areas. However, estrogen treatment decreased the amyloid precursor protein mRNA upregulation in these areas [42]. These data apparently demonstrate that estrogen may have an important role in reducing the upregulation of amyloid precursor protein mRNA in the postischemic period.

\section{Presenilins}

The products of the genes on chromosomes 14 and 1 were termed presenilin 1 and presenilin 2, respectively. Postischemic upregulation of presenilin 1 gene in neurons of the CA3 subfield of hippocampus and dentate gyrus was demonstrated [47]. Interestingly, a presenilin 1 mRNA reached the highest level on day 3 postischemia in affected areas. These data suggest that the upregulation of presenilin 1 mRNA may be associated with response of neurons injured by ischemia. In another study, the upregulation of presenilin mRNA was noted in the hippocampus, brain cortex and striatum, following ischemia [48]. Presenilin mRNA demonstrated the maximal rise in the hippocampus and brain cortex. The overexpression was larger on the contralateral side to the focal ischemic injury. This difference may reflect a loss of brain cells expressing presenilin genes on the ipsilateral side.

\section{Apolipoproteins}

The apolipoprotein E gene is located on chromosome 19. An increase in astrocytic apolipoprotein $\mathrm{E}$ mRNA expression, with the highest level on day 7 postischemia was noted, which suggests that ischemic neuronal injury results in the induction of certain genes within reactive astrocytes and this induction may be partly involved in the postischemic amyloidogenesis [49]. Postischemic apolipoprotein E mRNA upregulation in glia but not in neurons was seen in penumbra with a peak on the 21 st day. In ischemic core, the significant apolipoprotein $\mathrm{E}$ mRNA upregulation was found in macrophages [50]. Upregulation of apolipoprotein J mRNA was demonstrated in the penumbra in animal permanent focal brain ischemia. In these experiments, reactive astrocytes within the cortex were stained strongly for apolipoprotein J. It was concluded that upregulation of clusterin mRNA might contribute to the inflammation representing an important factor in secondary injury mechanisms after primary postischemic brain injury $[10,51]$.

Amyloid Precursor Protein Processing Secretases

The amyloid precursor protein is cleaved by $\alpha$-secretase and it is the non-amyloidogenic pathway. In an animal's brain, ischemia results in the down regulation of $\alpha$-secretase mRNA [52, 53]. In the second pathway, amyloid precursor 
protein is cleaved by $\beta$ - and $\gamma$-secretases to form soluble $\beta$-amyloid peptide [54]. The gene for $\beta$-secretase is located on chromosome 11. Recent data have shown that ischemia stimulates the expression, production and activity of $\beta$ secretase in postischemic brain [55-58]. Another study demonstrated for the first time the alteration in mRNA expression of three amyloid precursor protein metabolismrelated genes: $\beta$-secretase (BACE1), cathepsin B and glutaminyl cyclase mRNA, whose expression increased in hippocampus and cortex during postischemic period [59]. In 1 month that followed, the BACE1 mRNA level dropped but was still above the control level during the whole period of observation. Another evidence has shown that full-length presenilin interacts with immature $\beta$-secretase. This observation suggests that presenilin regulates $\beta$-secretase activity via direct interaction and facilitated trafficking of $\beta$-secretase to different compartments of cells [60]. Additionally, presenilin is involved in the amyloidogenic processing of amyloid precursor protein to produce $\beta$-amyloid peptide through the $\gamma$-secretase complex [61, 62]. $\gamma$-Secretase is a high molecular weight complex that consists of at least four components: presenilin-1 (PEN-1), nicastrin (Nct), anterior pharynxdefective-1 (APH-1) and presenilin enhancer-2 (PEN-2). Presenilin mRNA, which is upregulated in ischemic brain $[47,48]$, is involved in ischemic $\beta$-amyloid peptide production by $\gamma$-secretase complex [63]. The above findings will help to understand the gradual death of neurons during postischemic time, delayed $\beta$-amyloid peptide accumulation and long-term development of Alzheimer's-type dementia [64].

\section{Alzheimer's Proteins Detection in Experimental Brain Ischemia}

\section{Amyloid Precursor Protein}

Experimental postischemia, with a survival time of up to 1 year, showed strong brain staining to the $\mathrm{N}$ - and $\mathrm{C}$-terminal of amyloid precursor protein and also to the $\beta$-amyloid peptide. The demonstrated staining was intra- and extracellular $[4,13$, 26, 65-78]. Different fragments of amyloid precursor protein were shown in neurons, microglia, astrocytes, and oligodendrocytes $[4,71,73,79-83]$. Animals, with postischemia survival from 0.5 to 1 year, demonstrated strong brain staining only to the C-terminal of amyloid precursor protein and to the $\beta$-amyloid peptide $[4,6,68,72]$. The reactive astrocytes with accumulation of different parts of amyloid precursor protein might be involved in the development of glial scar $[4,73,79,80,82]$. Additionally, reactive astrocytic cells with pathological level of $\beta$-amyloid peptide accumulation might be involved in pathological repair of postischemic host tissue, including astrocytes death $[4,13$, $73,84,85]$.
A strong staining for C-terminal of amyloid precursor protein and $\beta$-amyloid peptide has been found in subcortical and periventricular white matter in the postischemic period $[6,8,9]$. The more intense postischemic injury of white matter is, the more extensive the staining of different parts of amyloid precursor protein in this field occurs [86]. Probably, the above mentioned kind of alterations is responsible for the occurrence of postischemic leukoaraiosis [9].

Extracellular deposits of different fragments of amyloid precursor protein ranged from small dots to regular amyloid plaques $[4-6,13,64,72,73,87-90]$. Widespread and multifocal plaques dominance in the postischemic hippocampus, entorhinal and brain cortex, corpus callosum, and adjacent to the lateral ventricles was observed. The deposition of the C-terminal of amyloid precursor protein within neurons and the $\beta$-amyloid peptide in astrocytic cells underscores the likely importance of these proteins in postischemic neurodegeneration [5, 13, 78-80, 87]. Moreover, the above deposits indicate that these structures may influence synaptic disintegration and trigger retrograde postischemic neuronal death [91]. Additionally, these results indicate that the late Cterminal of amyloid precursor protein and $\beta$-amyloid peptide accumulation postischemia may correspond to a secondary injury processes that could exacerbate the postischemic outcome by additional neuronal death $[2,6,7,36,68,71,72,74$, 75]. Postischemic $\beta$-amyloid peptide is generated as a result of neuronal damage/death [67] and probably shows its effects, interacting with ischemic brain cells, as dementia. It is accepted that $\beta$-amyloid peptide involves itself in neurons dying as neurotoxin [92]. The $\beta$-amyloid peptide is a neurotoxic protein and it forms a postischemic cascade of intracellular pathways in astrocytes, microglia, and oligodendrocytes that lead neurons and glia to damage and eventually to death [93, 94].

\section{Presenilins}

Staining of presenilins was more expressed in glia than in neurons and in a trace of the pyramidal cells of hippocampus during postischemic brain injury [14]. Presenilin 1 increases neuronal vulnerability to ischemia by raising intracellular calcium $[6,95]$. Recent studies have shown that presenilin 1 and intracellular calcium regulate neuronal glutamate uptake $[6,96]$. Taken together, these data indicate that presenilins and intracellular calcium may play an important role in regulating glutamate uptake, and therefore they may influence glutamate toxicity in the postischemic brain.

\section{Apolipoproteins}

During postischemic brain injury, a time-dependent accumulation of apolipoprotein $\mathrm{E}$ and $\mathrm{J}$ was noted in neurons of the CA1 and the CA2 subfields in the hippocampus 
undergoing delayed neuronal death [12]. Upregulation of apolipoprotein $\mathrm{E}$ and $\mathrm{J}$ mRNA, in contrast to neuronal protein deposition, appeared to be glial in origin with increases in mRNA in and around the hippocampus fissure, and only a weak signal over the CA1 and the CA2 pyramidal neurons. The above data seem to underpin the hypothesis that apolipoprotein $\mathrm{E}$ and $\mathrm{J}$ are synthesized in the astrocytes, secreted and then taken up by dying neurons [97-99]. Apolipoprotein E and $\mathrm{J}$ accumulation was observed in neurons destined to die by programmed cell death [12]. Furthermore, overexpression of apolipoprotein E and J suggests that the production of this protein was a result of selective delayed neuronal death rather than involvement in the cascade of events causing it [100]. The strong intra- and extracellular staining for apolipoproteins A1, E and J was noted in the postischemic period $[4,12,50,66,101]$. Intracellular staining was shown in both slightly and markedly ischemia-damaged neurons [4, 12]. Less often, staining for apolipoproteins in glia postischemia was detected [50].

Extracellular deposits of apolipoproteins were well delineated and diffuse. Strong staining was also shown in irregular, spider-like, acellular, necrotic foci [12, 67]. It is of interest to notice that deposits of apolipoproteins were colocalized with deposits of different parts of amyloid precursor protein [12]. Apolipoprotein E can promote the aggregation of soluble $\beta$ amyloid peptide into the oligomeric and the fibrillar form. Apolipoprotein $\mathrm{J}$ is implicated in transport of $\beta$-amyloid peptide across the blood-brain barrier. The main role of apolipoproteins $\mathrm{A} 1, \mathrm{E}$ and $\mathrm{J}$ in controlling the level of soluble $\beta$ amyloid peptide in the intra- and extracellular space of brain as well as their influence on oligomeric and fibrillar $\beta$-amyloid peptide generation is suggested. Apolipoprotein E increases $\beta$ amyloid peptide induced lysosomal leakage and apoptosis in neurons [102]. Apolipoproteins A1, E and J can influence the structure, toxicity, and accumulation of the $\beta$-amyloid peptide in postischemic brain. Apolipoproteins $\mathrm{E}$ and $\mathrm{J}$ may be involved in $\beta$-amyloid peptide production prior to its deposition. The above data demonstrate additional effects of both apolipoproteins on influencing $\beta$-amyloid peptide accumulation and prove that they play an important role in regulating extracellular brain $\beta$-amyloid peptide metabolism independent of $\beta$-amyloid peptide generation. These data indicate that apolipoproteins $\mathrm{A} 1, \mathrm{E}$ and $\mathrm{J}$ accumulation postischemia may be a secondary injury phenomenon, which could exacerbate healing of ischemic neurons and brain as a whole.

\section{Tau Protein}

Strong staining of tau protein in neurons was noted in the hippocampus [103] and the brain cortex [104, 105] postischemia [76]. Moreover, an increase of tau protein staining was found in astrocytes and oligodendrocytes, following ischemia [106, 107]. Pathologically modified tau protein was also observed in microglia around the ischemic focus [108]. These results indicate that only some neurons display changes in tau protein postischemia [106], which may reflect an early pathological state of the ischemic mechanisms in these cells [107]. Another study showed that tau itself had blocked transport of amyloid precursor protein from the neuron body into axons and dendrites, causing amyloid precursor protein accumulation in the neuronal body [109]. The recent study shows that postischemia, hyperphosphorylated tau protein accumulates in cortical neurons and colocalizes with signs of apoptosis $[15,110]$. The above data indicate that postischemic neuronal apoptosis is associated with tau protein hyperphosphorylation. Wen et al. $[15,111]$ reported that reversible postischemic injury is involved in neurofibrillary tangle-like tauopathy formation in the rat brain. The above data provide a neuropathological basis for the development of dementia following brain ischemia with Alzheimer's phenotype [111].

\section{Alpha-Synuclein}

Postischemic brain injury results in a presynaptic $\alpha$ synuclein accumulation in the hippocampus $[11,112]$. Robust $\alpha$-synuclein staining was noted in the perivascular space in the CA1 subfield of hippocampus postischemia in animals with long-term survival [112]. The degenerating sectors postischemia presented strong staining for $\alpha$ synuclein in glia [11]. The data that have just been presented suggest that $\alpha$-synuclein may be an important protein in the development of postischemic neurodegeneration [113]. The abnormal $\alpha$-synuclein deposition might disrupt synaptic function, resulting in cognitive disturbances [114]. The pathological metabolism of $\alpha$-synuclein influences the synaptic activity that may additionally promote retrograde neurons death in the postischemic brain [113].

\section{Detection of Alzheimer's Proteins in Human Ischemic Brain}

In the first study on the postischemic injury of human brain, Jendroska et al. $[16,17]$ have shown the relationship between postischemic injury and the accumulation of $\beta$ amyloid peptide. They have noted $\beta$-amyloid peptide deposits in diffuse and senile plaques and diffuse punctuate deposits in the cortex with small vessels close connection and finally accumulation in arterial boundary zones and sectors susceptible to ischemia. Additionally, they found an age-related increase in the accumulation of $\beta$-amyloid peptide, which correlated positively with increased number of plaques. $\beta$-Amyloid peptide plaques were mainly located in the boundary zone between posterior and middle cerebral artery and in the cortex around the Sylvian fissure. Occasionally, 
$\beta$-amyloid peptide accumulated in the center of arterial territory. It is of interest to notice that the middle layers of the cortex, which are highly vulnerable to ischemia, were most frequently affected by $\beta$-amyloid peptide.

In another study, brains after complete brain ischemia with survival time up to 1 month were used [20]. In all brains, strong staining for $\beta$-amyloid peptide in neurons and in perivascular space was noted. In seven cases, amyloid nonfibrillar plaques were also present. However, amyloid fibrillar plaques were only found in two brains. The neuronal staining varied depending on the brain area. Subcortical neurons were the most intensely stained. Neuronal bodies were filled with $\beta$-amyloid peptide granular deposits. Bodies of hippocampal neurons were intensely stained but perikarya of pyramidal neurons in the CA2 and CA3 subfields and their proximal dendrites were stained stronger than neurons of the CA1 area. In contrast, the staining of dentate gyrus appeared to be weak. In the brain cortex, the staining of the neurons appeared as granular deposits in the periphery of the neurons but in other neurons the intensity labeled grains were noted in apical dendrites. The intensity of neuronal cytoplasm staining decreased or completely disappeared in the sectors with ischemic damage. However, neurons surrounding the above areas showed strong staining for apolipoprotein E. Some positive neurons for apolipoprotein $\mathrm{E}$ were also labeled with antibody against tau- 1 and by thioflavine S. Additionally, epithelial and ependymal cells were stained for $\beta$-amyloid peptide. In seven brains, many nonfibrillar plaques were noted in the brain cortex. The amyloid nonfibrillar plaques mainly were connected with neurons. Serial brain sections stained with the Bielschowsky method demonstrated some amyloid plaques which were weakly stained. The shape of plaques varied from cap-like to oval and round. Some of these plaques were stained positively by thioflavine. In all brains, vessels of white and gray matter were surrounded by $\beta$-amyloid peptide deposits. The deposits had cuffs or droplets shape. It is of interest that in two brains a few fibrillar plaques were noted. In four cases, walls of meningeal and cortical vessels showed staining for $\beta$-amyloid peptide. In some brains, plaques were stained for apolipoprotein E. Apolipoprotein E, a $\beta$-amyloid peptide associated chaperone, is of importance in the processes of soluble $\beta$-amyloid peptide fibrillization [115]. In all cases around blood-brain barrier vessels weak staining for $\beta$-amyloid peptide was found. $\beta$-Amyloid peptide deposition around the blood-brain barrier vessels suggested that amyloid originated from blood. Evidence supporting the above idea derives from a recent study, which indicates that circulating $\beta$ amyloid peptide has been elevated in patients after acute ischemic brain injury [39, 41$]$.

According to the next study, $\beta$-amyloid peptide and apolipoprotein $\mathrm{E}$ are linked with human postischemic hippocampus. Qi et al. [19] investigated the accumulation and distribution of $\beta$-amyloid peptide $1-40, \beta$-amyloid peptide
1-42 and apolipoprotein $\mathrm{E}$ in human postischemic hippocampus. They have demonstrated that the accumulation of both types of $\beta$-amyloid peptide was elevated following ischemic brain injury. Neuronal apolipoprotein E staining was also significantly increased in the CA1 and CA3 subfields of ischemic hippocampus. Furthermore, the postischemic changes of $\beta$-amyloid peptide $1-40, \beta$-amyloid peptide 1-42 and apolipoprotein E staining in the CA1 and CA3 areas were very similar temporally, although the upregulation extent and peak increases of $\beta$-amyloid peptide $1-40$ and $\beta$-amyloid peptide 1-42 in the CA3 sector were lower than those found in the CA1 area, respectively. It was presented that $\beta$-amyloid peptide $1-40$, $\beta$-amyloid peptide $1-42$ and apolipoprotein E would be upregulated in the human postischemic brain injury. This overexpression of different forms of $\beta$-amyloid peptide may contribute to the progression of ischemic brain injury and finally to Alzheimer's-type dementia.

\section{Postischemic Dementia with Alzheimer's Phenotype}

\section{In Animals}

In addition to ischemic neuronal lesions, behavioral changes have been shown, too $[2,3,36,116]$. Postischemic injury does not result in long-lasting neurological deficits in animals [116]. Spontaneous recovery of sensorimotor function has been noted in the postischemic period [2, 117, 118]. Following ischemic brain injury, locomotor hyperactivity has been observed [119, 120] as in Alzheimer's disease individuals. The hyperactivity was associated with neuronal death in hippocampus [120]. Longer ischemia and longer locomotor hyperactivity, which is positive, correlated with increased pyramidal neurons loss in hippocampus with neuroinflammation [10, 64, 116, 121]. After ischemic brain injury, impairment in habituation, as revealed by an increase in exploration time, was observed [122, 123]. Brain ischemia results in reference and working memory deficits [2, $124,125]$. Moreover, ischemic brain injury in animals leads progressively to spatial memory deficits during the survival period [2, 126, 127]. Progression of cognitive impairment has been shown each time during recirculation [2, 127, 128]. In addition to that, evidence from repetitive ischemic brain injury in animals has shown persistent locomotor hyperactivity, severe cognitive deficits and reduced anxiety [129]. The behavioral functional changes, mentioned above, were associated with significant brain atrophy [4-6, 130] and diffuse neuronal loss in the CA1 subfield of hippocampus, brain cortex, caudate nucleus [6, 64, 129], amygdala, and perirhinal cortex [1]. Alertness and sensorimotor capacities are affected for 1-2 days whereas the deficits in learning and memory seem to be irreversibly progressing and lasting for $\operatorname{good}[2,121]$. 


\section{In Humans}

Postischemic injury in humans is the most common chronic cause of disability worldwide and generally has a negative influence on the patients it affects, caregivers and society as a whole [131]. Brain ischemia survivors suffer from progressing neurological disabilities that significantly influence their ability to return to society. A more insidious consequence of ischemic brain injury is a postischemic dementia $[32,132]$ that is also linked with severe disability. The global scale of the problem and enormous costs involved make it clear that there is an urgent need for advances in the prevention of ischemic brain injury and its consequences like postischemic dementia. Dementia is the worst consequence for survivors following brain ischemia and it is responsible for approximately $20 \%$ of all confirmed dementias [133]. Globally, dementia, following stroke, varies from $10 \%$ to $50 \%$ depending on the diagnostic criteria, geographic location and population demographic [134]. In fact, it is becoming clear that postischemic dementia has many risk factors in common with sporadic Alzheimer's disease currently. Indeed, brain ischemic injuries may precede the onset of this form of dementia, strongly suggesting that brain ischemic episodes may trigger neurodegenerative dementias. Postischemic dementia associated with chronic delayed secondary injury occurs in patients suffering from focal, lacunar and salient brain ischemia in a progressive manner $[32,132,135]$. The progressive postischemic injury has received far less attention in clinical and experimental dementia studies.

Epidemiological studies have shown that the prevalence of dementia in postischemic brain injury individuals is 9fold higher than in controls after 3 months [136-138] and 4-12 times higher than in controls 4 years after a lacunar infarct [139]. Different patterns of cognitive decline, as a result of postischemic injury, have been evident by longitudinal epidemiological studies, which have demonstrated a progressive course of dementia resulting from postischemia. Tatemichi et al. [140] demonstrated that the incidence of dementia amounted to $7 \%$ among patients after 1 year postischemia. Bornstein et al. [135] reported that $32 \%$ of patients, who were initially free of dementia, developed it during 5 years following first ischemic episode. Henon et al. [141] claimed that the cumulative proportion of patients with dementia was $21 \%$ after 3 years of survival. Altieri et al. [142] examined patients in the postischemic period for 4 years and noted that the incidence of dementia amounted to $22 \%$ by the end of the follow-up time. In long term-based studies of postischemic dementia in patients, Kokmen et al. [143] noted that the incidence of dementia amounted to $7 \%$ at 1 year, $10 \%$ at 3 years, $15 \%$ at 5 years and $23 \%$ at 10 years. Desmond et al. [144] performed functional assessments of postischemic patients annually and noted a progressive course of dementia with the incidence rate of $9 / 100$ persons/year. In two studies, based on patients with a lacunar ischemia as their first ischemic episode, Samuelsson et al. [145] found that $5 \%$ and $10 \%$ of patients had dementia after 1 and 3 years of survival, respectively, and Loeb et al. [139] reported that $23 \%$ of patients had dementia during an average of 4 years of observation.

Removal of the above abnormalities is an issue that neurologists and scientists devote little time to. In some patients, a spontaneous functional restoration is noted during weeks/months postischemia. However, in general, this spontaneous recovery is incomplete. Moreover, ischemic brain injury often leaves its victims functionally devastated and, as such, is the leading cause of permanent disability requiring long-term institutional care. The loss of life quality for years and health care resources are staggering. The situation is even aggravated by the fact that unlike many cases of other neurological diseases, no safe, effective therapy is available for the majority of patients with acute brain ischemia. The social burden after brain ischemia is dramatically increasing. Thus, understanding of the underlying progressing pathological processes is urgently needed. This review tends to summarize the neuropathological changes of chronic postischemic brain injury and reveal the convincing mechanisms.

Taken together, underpinning evidences from both clinical and experimental investigations showed that the progressive decline of cognitive activities could not be explained only by the direct contribution of the primary ischemic brain injury, but rather by a progressive consequence of the additive effects of the postischemic injury, Alzheimer's factors and aging $[36,54,94,117,121,132]$. The above data suggest that brain ischemia enhances amyloid precursor protein mRNA expression, which may be partly involved in the progression of cognitive impairment in the postischemic period [42, 43, 54]. At last the generation of $\beta$-amyloid peptide in postischemic brain increases which impairs the memory [53]. Additionally, pathological postischemic accumulation of $\alpha$-synuclein might disrupt synaptic activity, resulting in cognitive suffering [114]. The functional abnormalities precede the neuronal degeneration within the areas of selective vulnerability to ischemia. What is more, areas of brain, which are devoid of ischemic neuronal injury, display functional abnormalities. The above alterations seem to be mainly due to synaptic insufficiency in connections of neuronal cells within areas with ischemically damaged or dead neurons.

\section{Brain Ischemia as Trigger of Sporadic Alzheimer's Disease}

Alzheimer's disease is characterized by loss of neurons, amyloid plaques generation/deposition, neurofibrillary tangles, cerebral amyloid angiopathy and dementia development. In Alzheimer's disease, there is a positive correlation 
between areas with heavy $\beta$-amyloid peptide accumulation and those which are damaged in the brain [146-148]. On the other hand, quantitative measure of $\beta$-amyloid peptide level did not correlate with Alzheimer's disease duration [149]. This may be interpreted as follows: it seems that $\beta$-amyloid peptide could not continue accumulating in the brain during the disease duration. Although the extent of neuronal loss is directly correlated with the intensification of dementia [150], the mechanism(s) leading to the neuronal cells death still remain unclear. It is a matter of controversy whether the pathological cascade of $\beta$-amyloid peptide in Alzheimer's disease is primarily triggered by intraneuronal or extracellular accumulations of $\beta$-amyloid peptide and will contribute directly or indirectly, if at all, to Alzheimer's disease development with massive neurons loss [151-153]. Other data demonstrated that neuronal death is coincided with neurofibrillary tangles [154], which are composed by hyperphosphorylated aggregates of the microtubuleassociated tau protein in some neurodegenerative disorders known as tauopathies, of which Alzheimer's disease is one of the most notable. Recent investigation on transgenic animals demonstrates that the mechanism of neuronal death did not correlate with the presence of tau protein filament formation within individual neurons which are going to die, suggesting that neuronal death can occur independently of generation of neurofibrillary tangles [154]. Moreover, there is evidence to underpin the above results that some neurons in Alzheimer's disease may die without forming neurofibrillary tangles [150]. It can be concluded that there is no relationship between amyloid plaques and neurofibrillary tangles and developing dementia in Alzheimer's disease, and amyloid plaques and neurofibrillary tangles may arise as independent alterations and can result from a neurodegenerative processes rather than being their cause $[21,155$, 156]. These results seem to provide additional evidence that neuronal death may not result directly and/or primarily from amyloid plaques [157] and formation of neurofibrillary tangles but rather it might be associated with other pathological factor(s). Another important pathological element in Alzheimer's disease is $\beta$-amyloid peptide deposition in brain small vessels. The $\beta$-amyloid peptide accumulation in brain small vessels causes wall pathology in vascular network and results in blood-brain barrier changes and focal "no-reflow phenomenon" [6, 158-160]. The collapse of such a barrier leads to spread blood $\beta$-amyloid peptide into the surrounding brain parenchyma [160]. Examination of amyloid plaques made by using serial sections of Alzheimer's disease brains for both electron and light microscopy in order to observe the relationship between plaques and microvessels can be summarized as follows: (1) The cores of the typical senile plaques appear in tight contact with the microvessels and the $\beta$-amyloid peptide spread into the surrounding brain parenchyma. The composition of senile plaques core includes complement factors and immunoglobulins [155]. The presence of immune proteins within the plaques core suggests that blood immunological components could be entangled in the structure of $\beta$-amyloid peptide deposits. (2) Different types of plaques have a close link to the capillaries. (3) Both confocal laser scanning microscopy and scanning electron microscopy demonstrated a direct link between the $\beta$-amyloid peptide and vascular network, especially $\beta$-amyloid peptide 1-40. Additionally, confocal laser scanning microscopy has demonstrated that $\beta$-amyloid peptide 1-40 depositions occur in and around neurovessels [161]. The above mentioned results seem to indicate that some changes of the blood-brain barrier can induce transport of blood $\beta$-amyloid peptide 1-40 into the brain parenchyma of Alzheimer's disease patients. (4) The global atrophy of the brain, especially of the hippocampus and dysfunction of astrocytic cells (vascular end-feet) are common hallmarks in Alzheimer's disease. From this point of view, alteration of the blood-brain barrier is an important element with regard to the neuropathological damage observed in Alzheimer's disease brains [162].

The discovery of mutations within amyloid precursor protein gene led to the suggestion of primary pathological role for amyloid precursor protein in Alzheimer's disease. This data has supported the formulation of the "amyloid hypothesis" of Alzheimer's disease in which the deposition of $\beta$-amyloid peptide is the trigger of neuropathological events in Alzheimer's disease and of all subsequent pathologies. Nevertheless, the etiology based on "amyloid hypothesis" of sporadic Alzheimer's disease has not yet been cleared up and probably is baseless. The results presented so far suggest that amyloid precursor protein and presenilin genes overexpression may not be the direct cause of different forms of Alzheimer's disease cases but probably they could influence the neurochemical components of a resulting pathology, and therefore indirectly affect the levels of neurotoxicity and extent of secondary neurodegeneration [94]. Conversely, in transgenic animal brains, with high blood levels of $\beta$-amyloid peptide in systemic circulation, no detectable depositions of $\beta$-amyloid peptide appeared [163]. Basing upon evidence of no difference in the level of blood $\beta$-amyloid peptide $1-40$ and $\beta$-amyloid peptide 1-42 among cases of sporadic Alzheimer's disease and control individuals [164], finding out that more numerous deposits of $\beta$-amyloid peptide 1-40 and $\beta$-amyloid peptide 1 42 were noted in brains of Alzheimer's disease patients than in controls strongly suggests that a certain dysfunction of the blood-brain barrier could induce an abnormal passage of $\beta$ amyloid peptide from systemic circulation to the brain tissue in Alzheimer's disease patients [161]. Additionally, Scholz [165] described plaque-like degeneration of arteries and capillaries and considered that the core of senile plaques might consist of material that had permeated from the circulatory 
network. Therefore passage to and accumulation of serum $\beta$ amyloid peptide into the surrounding brain parenchyma and vessel wall may require interrupted blood-brain barrier. Some risk factors for Alzheimer's disease development like brain ischemia are known to disrupt blood-brain barrier integrity and thereby can allow transportation of peripheral $\beta$-amyloid peptide into the surrounding brain parenchyma $[89,158-160$, 166-168]. For this reason, a detailed study on the role of ischemic factor in sporadic Alzheimer's disease should be carried out as a priority. One of the biggest stumbling blocks in developing effective drug therapy for Alzheimer's disease has been the lack of a comprehensive hypothesis that explains the mechanism behind all pathological changes seen in patients suffering from Alzheimer's disease [38, 169].

It should be mentioned that there is still controversy whether ischemic-type dementia is a different entity from Alzheimer's disease dementia or merely two extreme descriptions of the same clinical condition. Currently, a considerable and growing body of evidence suggests that ischemic mechanism(s) are present in Alzheimer's disease [22-25, 38, $160,170]$. Lately, brain ischemia has been recognized as a factor lowering the threshold of neuronal death [171]. Neuropathological post mortem examinations of Alzheimer's disease brains have shown that $30 \%$ of patients showed evidence of postischemic injury [3,29] and the cases with both Alzheimer's disease and brain ischemia demonstrated more severe cognitive impairment than those without brain ischemia $[172,173]$. Some studies from transgenic mice demonstrated that neuronal death, a common feature of Alzheimer's disease, is not dependent on $\beta$-amyloid peptide $[155,157,174]$. Other study indicates that $\beta$-amyloid peptide is generated as a response to ischemic neuronal injury [67] and probably produces its effects by interacting with cell surface molecules commonly encountered in the ischemic brain. In human cases with brain ischemia, $\beta$-amyloid peptide was found in neuronal bodies and around dystrophic neurites and accumulation of $\beta$-amyloid peptide was similar to depositions seen in Alzheimer's disease [16-18, 20]. Thus, the increased staining of different parts of amyloid precursor protein may be a reaction of the brain to ischemic neuronal injury. On the other hand, increased synthesis and metabolism of amyloid precursor protein in patients with brain ischemia may be an acute response of protein to brain ischemic injury leading to the deposition of $\beta$-amyloid peptide. We propose that amyloid precursor protein $/ \beta$-amyloid peptide is involved in the course of the disease secondarily in order to help maintain neuronal network function [175]. Tau protein pathology can also be a part of the neuronal reaction to brain ischemia [76]. Experimental brain ischemic injury has also resulted in overexpression of amyloid precursor protein mRNA in the brain cortex and hippocampus implying that the production and metabolism of amyloid precursor protein may be a characteristic response to loss of functional activity by ischemic brain $[54,94]$. To support these conclusions, different parts of amyloid precursor protein were found in ischemic neuronal bodies, axonal swellings and dystrophic neurites [56, 176, 177]. The evidences mentioned above point to the degeneration of some pathways. In ischemic brain, diffuse plaques are connected with field of clusters of neuronal perikarya and the shape of staining frequently covered dendrite area. In Alzheimer's disease, the predominance of neuronal mRNAs in individual plaques was observed [178], which suggests that the amyloid plaques develop in the areas where neurons die [67]. The demonstrated data support the idea that amyloid precursor protein is upregulated in neurons as an effect of their injury and/or loss of functional innervations, and therefore, that the early development of diffuse plaques in Alzheimer's disease may be a result of neuronal degeneration. Different studies support a general conclusion that the formation of amyloid plaques and neurofibrillary tangles is a reactive alteration that appears in response to neuronal ischemic injury and is not strictly related to dementia $[67,155]$. Nevertheless, $\beta$-amyloid peptide is a neurotoxin when produced and may start processes of secondary neuronal injury. Other data also suggest that tau protein pathology is a result of neurodegenerative changes [76] within brain cellular perikarya following synaptic disconnection in brain network. It can be concluded that amyloid plaques and tau protein changes arise independently. However, once initiated, pathological processes can mutually cooperate $[179$, 180]. If $\beta$-amyloid peptide and tau protein alterations are the product of neurodegeneration thus, probably, these two proteins are hallmarks of late stages in sporadic Alzheimer's disease development.

We would like to put forward a theoretical scheme that fits very well with ischemia basis of sporadic Alzheimer's disease. According to our theory, Alzheimer's disease would start to develop when at least two pathological events converge: brain ischemia and ischemic chronic insufficiency of blood-brain barrier for $\beta$-amyloid peptide $[6,8,38,88,89$, $170,181]$. These two cases create two main neuropathologies; brain ischemia is responsible for acute and delayed neuronal death in hippocampus and dysfunctional, dying and dead neurons in other areas affected by ischemically induced $\beta$-amyloid peptide of the brain with global brain atrophy, and ischemic chronic blood-brain barrier insufficiency creating mainly amyloid pathology in surrounding brain tissue $[160,167]$. The magnitude and extent to which the blood-brain barrier is exposed appears to be minimal since acute alterations such as microinfarcts [88] were not easily observed. Still, these neuropathology remains of great consequence to the brain tissue and appears to be cumulative over time. Transgenic mice that accumulate $\beta$-amyloid peptide without neuronal loss in hippocampus support directly the above idea $[155,157,174]$. The neuropathology of 
Alzheimer's disease is rooted in ischemic pathology what is indicated by evidence growing recently [14, 22-28, 160, 182]. The "amyloid hypothesis" of Alzheimer's disease and the "ischemia-reperfusion theory" of Alzheimer's disease may together explain Alzheimer-type neurodegeneration in the brain. Therefore, overexpression of different parts of amyloid precursor protein in brain after ischemia and ischemia alone probably constitute a vicious cycle that leads to neurodegeneration with dementia [6, 129]. We hypothesize that initial acute upregulation of amyloid precursor protein in the ischemic brain is a cellular neuroprotective response to ischemic injury [175]; however, long-term overexpression of $\beta$-amyloid peptide in brain may contribute to neurotoxicity. Progressing death of neurons after ischemia-reperfusion may be caused not only by degeneration processes of neurons destroyed during primary ischemia but also by ischemic opening of blood-brain barrier with deposition and influence of cytotoxic fragments of amyloid precursor protein on ischemic neurons and their processes [89]. In this review, we discuss the role of pathways that are invoked during ischemia-reperfusion injury and may potentially develop injury in Alzheimer's disease brain. The fundamental thesis of our proposal is that the pathology seen in Alzheimer's disease is a continuous process starting from the initial ischemic neuronal damage $[4,5,26,87]$ to the well-established extravasations of $\beta$ amyloid peptide from blood across ischemic blood-brain barrier [88, 89, 160, 166-168], culminating in the formation of amyloid plaques.

\section{Ischemic Blood-Brain Barrier as Final Maturation Factor in Sporadic Alzheimer's Disease}

In contrast to classical view of sporadic Alzheimer's disease, recent data indicate that ischemia-reperfusion injury contributes to progressing degeneration in Alzheimer's disease [4, 6, 13, 14, 23-25, 27, 28, 183]. We suggest that the ischemic blood-brain barrier maturation hypothesis of Alzheimer's disease implying that pathological permeability and faulty clearance of $\beta$-amyloid peptide across the ischemic bloodbrain barrier could act as seeds for the process that is responsible for $\beta$-amyloid peptide accumulation as plaques and maturation in Alzheimer's disease neurodegeneration progression [30, 36, 90, 160, 166-168, 170, 181]. This would lead to premature senescence of microcirculatory system and insufficient angiogenesis of blood-brain barrier vessels, neurovascular system regression and inflammation [10]. Finally, we could observe repeated brain ischemic insults with repeated blood-brain barrier dysfunction [6]. It is conceivable that dysfunction in blood-brain barrier cells within the microvascular system could disrupt this system and inaugurate the neuropathogenic disease cascade connected with pathological $\beta$-amyloid peptide generation and deposition
[184]. We would like to put forward a theoretical scheme that fits very well with ischemia basis of sporadic Alzheimer's disease etiology. In our proposal, Alzheimer's disease would start to develop when at least two neuropathological events converge: brain ischemia and ischemic opening of bloodbrain barrier. These two events create two main pathologies; brain ischemia is responsible for neuronal death in hippocampus [4-7] and chronic ischemic blood-brain barrier insufficiency is creating amyloid cascade with amyloid plaques formation $[30,90,181]$. We demonstrated a considerable evidence indicating that the pathogenesis of sporadic Alzheimer's disease is rooted in ischemic pathology. Based on this proposal, we suggest some new therapeutic approaches that could be used in Alzheimer's disease to prevent permeability of ischemic blood-brain barrier for $\beta$-amyloid peptide $[38,169]$ and enhance reverse $\beta$-amyloid peptide clearance from brain parenchyma following ischemia-reperfusion injury [36, 168].

\section{Conclusions}

The typical elements of Alzheimer's disease pathology in postischemic brain are Alzheimer's disease-associated overexpression of genes and abnormal generation of proteins, various kinds of amyloid plaques, and neuronal death with inflammation in specific brain fields as hippocampus with final development of dementia. Causes of plaques, up to the present, were taken as heterogeneous and neuronal death as a consequence of neurotoxic futures of $\beta$-amyloid peptide. New data suggest that brain ischemia triggers parallel induction of neuronal death and Alzheimer's type genes with subsequent development of plaques and detected hippocampus and brain atrophy [4-6, 94, 130], which is indispensable in final formation of dementia $[2,3]$. We demonstrated the data of Alzheimer's phenotype and genotype in postischemic brain seemed to underpin directly the ischemic hypothesis of sporadic Alzheimer's disease etiology. The occurrence of different parts of amyloid precursor protein as plaques and phosphorylated tau protein found in neurofibrillary tangles in postischemic brains strongly establishes a close association between brain ischemia and sporadic Alzheimer's disease [4, 7, 13, 15, 18-20, 37, 38, $75,185]$. Neuropathological post mortem examinations of Alzheimer's disease brains have shown that $30 \%$ of patients showed evidence of postischemic injury [3, 24, 29], and the cases with both Alzheimer's disease and brain ischemia demonstrated more severe cognitive impairment than those without brain ischemia $[172,173]$. A recent study found that brain ischemia in hippocampus aggravates cognitive impairment by neuronal death, promotion of $\beta$-amyloid peptide generation and deposition, [3, 64] and by pathological phosphorylation of tau protein in ischemic cells [15], finally 
underpinning the idea that the augmentation of inflammatory reactions [10] might be responsible for brain ischemia induced as vicious cycle aggravation of cognitive impairment in Alzheimer's disease [3, 6].

In summary, we presented good ischemic model(s) for Alzheimer's disease investigation. By use of brain ischemia model(s), we may elucidate the neuropathology of Alzheimer's disease. Present knowledge regarding the induction of genes, neuropathophysiology and neuropathology of brain ischemia and Alzheimer's disease indicates that the same processes contribute to neuronal death, amyloid generation and accumulation, tau protein hyperphosphorylation and brain parenchyma disintegration with full-blown dementia of Alzheimer's phenotype $[2,13,15,25,38]$.

Acknowledgments This study was supported in part by funds from: Mossakowski Medical Research Centre, Polish Academy of Sciences (T4 RP), Medical University of Lublin (DS338 MJ, DS403/13 WFJ, DS201/ 13 RM, DS475/12 SJC) and Polish Ministry of Science and Higher Education (No: N N405 162639 ABK). The paper was developed using the equipment purchased within the Project "The equipment of innovative laboratories doing research on new medicines used in the therapy of civilization and neoplastic diseases" within the Operation Program Development of Eastern Poland 2007-2013, Priority Axis I Modern Economy, Operations I.3 Innovation Promotion.

\section{Conflict of interest None}

Open Access This article is distributed under the terms of the Creative Commons Attribution License which permits any use, distribution, and reproduction in any medium, provided the original author(s) and the source are credited.

\section{References}

1. Barra de la Tremblaye P, Plamondon H (2011) Impaired conditioned emotional response and object recognition are concomitant to neuronal damage in the amygdale and perirhinal cortex in middle-aged ischemic rats. Behav Brain Res 219:227-233

2. Kiryk A, Pluta R, Figiel I, Mikosz M, Ułamek M, Niewiadomska G, Jabłoński M, Kaczmarek L (2011) Transient brain ischemia due to cardiac arrest causes irreversible long-lasting cognitive injury. Behav Brain Res 219:1-7

3. Li J, Wang YJ, Zhang M, Fang CQ, Zhou HD (2011) Cerebral ischemia aggravates cognitive impairment in a rat model of Alzheimer's disease. Life Sci 89:86-92

4. Pluta R (2000a) The role of apolipoprotein E in the deposition of $\beta$-amyloid peptide during ischemia-reperfusion brain injury. A model of early Alzheimer's disease. Ann NY Acad Sci 903: 324-334

5. Pluta R (2002a) Astroglial expression of the beta-amyloid in ischemia-reperfusion brain injury. Ann NY Acad Sci 977:102-108

6. Pluta R, Ułamek M, Jabłoński M (2009) Alzheimer's mechanisms in ischemic brain degeneration. Anat Rec 292:1863-1881

7. Pluta R, Jabłoński M, Czuczwar SJ (2012b) Postischemic dementia with Alzheimer phenotype: selectively vulnerable versus resistant areas of the brain and neurodegeneration versus $\beta$-amyloid peptide. Folia Neuropathol 50:101-109
8. Pluta R, Ułamek M, Januszewski S (2006) Micro-blood-brain barrier openings and cytotoxic fragments of amyloid precursor protein accumulation in white matter after ischemic brain injury in long-lived rats. Acta Neurochir Suppl 96:267-271

9. Pluta R, Januszewski S, Ułamek M (2008) Ischemic blood-brain barrier and amyloid in white matter as etiological factors in leukoaraiosis. Acta Neurochir Suppl 102:353-356

10. Sekeljic V, Bataveljic D, Stamenkovic S, Ułamek M, Jabłoński M, Radenovic L, Pluta R, Andjus PR (2012) Cellular markers of neuroinflammation and neurogenesis after ischemic brain injury in the long-term survival rat model. Brain Struct Funct 217: $411-420$

11. Ishimaru H, Ueda K, Takahashi A, Maruyama Y (1998) Changes in presynaptic protein NACP/alpha-synuclein in an ischemic gerbil hippocampus. Brain Res 788:311-314

12. Kida E, Pluta R, Lossinsky AS, Golabek AA, Choi-Miura NH, Wisniewski HM, Mossakowski MJ (1995) Complete cerebral ischemia with short-term survival in rat induced by cardiac arrest: II. Extracellular and intracellular accumulation of apolipoproteins $\mathrm{E}$ and $\mathrm{J}$ in the brain. Brain Res 674:341-346

13. Pluta R, Kida E, Lossinsky AS, Golabek AA, Mossakowski MJ, Wisniewski HM (1994b) Complete cerebral ischemia with shortterm survival in rats induced by cardiac arrest: I. Extracellular accumulation of Alzheimer's $\beta$-amyloid protein precursor in the brain. Brain Res 649:323-328

14. Pluta R (2001) Proteins associated with Alzheimer's disease in conditions predisposing to Alzheimer's-type neurodegeneration. J Cereb Blood Flow Metab 21(suppl 1):S424

15. Wen Y, Yang SH, Liu R, Perez EJ, Brun-Ziukemagel AM, Koulen P, Simpkins JW (2007) Cdk5 is involved in NFT-like tauopathy induced by transient cerebral ischemia in female rats. Biochim Biophys Acta 1772:473-483

16. Jendroska K, Poewe W, Daniel SE, Pluess J, Iwerssen-Schmidt H, Paulsen J, Barthel S, Schelosky L, Cervos-Navarro J, DeArmond SJ (1995) Ischemic stress induces deposition of amyloid beta immunoreactivity in human brain. Acta Neuropathol 90:461-466

17. Jendroska K, Hoffmann OM, Patt S (1997) Amyloid $\beta$ peptide and precursor protein (APP) in mild and severe brain ischemia. Ann NY Acad Sci 826:401-405

18. Maślińska D, Laure-Kamionowska M, Taraszewska A, Deręgowski K, Maśliński S (2011) Immunodistribution of amyloid beta protein $(\mathrm{A} \beta)$ and advanced glycation end-product receptors (RAGE) in choroid plexus and ependyma of resuscitated patients. Folia Neuropathol 49:295-300

19. Qi J, Wu H, Yang Y, Wand D, Chen Y, Gu Y, Liu T (2007) Cerebral ischemia and Alzheimer's disease: the expression of amyloid- $\beta$ and apolipoprotein $\mathrm{E}$ in human hippocampus. $\mathrm{J}$ Alzheimers Dis 12:335-341

20. Wiśniewski HM, Maślińska D (1996) Beta-protein immunoreactivity in the human brain after cardiac arrest. Folia Neuropathol 34:65-71

21. Alzheimer A (1911) Uber eigenartige Krankheitsfaelle des Spaetern Alters, Zeitschrift fuer die gesamte. Neurol Psych 4:256-286

22. Bell R, Zlokovic B (2009) Neurovascular mechanisms and blood-brain barrier disorders in Alzheimer's disease. Acta Neuropathol 118:103-113

23. De la Torre JC (2005) Is Alzheimer's disease preceded by neurodegeneration or cerebral hypoperfusion? Ann Neurol $57: 783-784$

24. Kalaria RN (2000) The role of cerebral ischemia in Alzheimer's disease. Neurobiol Aging 21:321-330

25. Niedermeyer E (2007) Consideration of the ischemic basis and therapy of Alzheimer disease. Clin EEG Neurosci 38:55-56

26. Pluta R (1997a) Experimental model of neuropathological changes characteristic for Alzheimer's disease. Folia Neuropathol 35:94-98

27. Pluta R (2004a) Alzheimer lesions after ischemia-reperfusion brain injury. Folia Neuropathol 42:181-186 
28. Pluta R (2004b) From brain ischemia-reperfusion injury to possible sporadic Alzheimer's disease. Curr Neurovasc Res 1:441-453

29. Pluta R (2006a) Ischemia-reperfusion factors in sporadic Alzheimer's disease. In: Welsh EM (ed) New research on Alzheimer's disease. Nova Science Publishers, Inc, New York, pp 183-234

30. Pluta R (2006b) Is the ischemic blood-brain barrier insufficiency responsible for full-blown Alzheimer's disease? Neurol Res 28:266-271

31. Pluta R, Ułamek M (2006) Brain amyloidosis following ischemia-reperfusion injury. Curr Trends Neurol 2:41-46

32. Pinkston JB, Alekseeva N, Gonzalez Toledo E (2009) Stroke and dementia. Neurol Res 31:824-831

33. Querfurth HW, LaFerla FM (2010) Alzheimer's disease. N Engl J Med 362:329-344

34. Pluta R (2011) Unresolved questions concerning etiology of Alzheimer's disease: hypometabolism. Nutrition 27:1-2

35. Arshavsky YI (2010) Why Alzheimer's disease starts with a memory impairment: neurophysiological insight. J Alzheimers Dis 20:5-16

36. Pluta R, Jolkkonen J, Cuzzocrea S, Pedata F, Cechetto D, PopaWagner A (2011) Cognitive impairment with vascular impairment and degeneration. Curr Neurovasc Res 8:342-350

37. Pluta R (2007) Ischemia-reperfusion pathways in Alzheimer's disease. Nova Science Publishers Inc., New York

38. Pluta R, Ułamek M, Jabłoński M (2010b) Consideration of the ischaemic basis and treatment of Alzheimer's disease. Folia Neuropathol 48:11-26

39. Lee PH, Bang OY, Hwang EM, Lee JS, Joo US, Mook-Jung I, Huh $\mathrm{K}$ (2005) Circulating beta amyloid peptide is elevated in patients with acute ischemic stroke. J Neurol Transm 112:1371-1379

40. Mörtberg E, Zetterberg H, Nordmark J, Blennow K, Catry C, Decraemer H, Vanmechelen E, Rubertsson S (2011) Plasma tau protein in comatose patients after cardiac arrest treated with therapeutic hypothermia. Acta Anaesthesiol Scand 55:1132-1138

41. Zetterberg H, Mörtberg E, Song L, Chang L, Provuncher GK, Patel PP, Ferrell E, Fournier DR, Kan CW, Campbell TG, Meyer R, Rivnak AJ, Pink BA, Minnehan KA, Piech T, Rissin DM, Duffy DC, Rubertsson S, Wilson DH, Blennow K (2011) Hypoxia due to cardiac arrest induces a time-dependent increase in serum amyloid $\beta$ levels in humans. PLoS One 6(12):e28263. doi:10.1371/journal.pone

42. Shi J, Panickar KS, Yang SH, Rabbani O, Day AL, Simpkins JW (1998) Estrogen attenuates over-expression of beta-amyloid precursor protein messenger RNA in an animal model of focal ischemia. Brain Res 810:87-92

43. Shi J, Yang SH, Stubley L, Day AL, Simpkins JW (2000) Hypoperfusion induces overexpression of $\beta$-amyloid precursor protein mRNA in a focal ischemic rodent model. Brain Res 853:1-4

44. Kim HS, Lee SH, Kim SS, Kim YK, Jeong SJ, Ma J, Han DH, Cho BK, Suh YH (1998) Post-ischemic changes in the expression of Alzheimer's APP isoforms in rat cerebral cortex. NeuroReport 9:533-537

45. Abe K, Tanzi RE, Kogure K (1991) Selective induction of Kunitz-type protease inhibitor domain-containing amyloid precursor protein mRNA after persistent focal ischemia in rat cerebral cortex. Neurosci Lett 125:172-174

46. Koistinaho J, Pyykonen I, Keinanen R, Hokfelt T (1996) Expression of $\beta$-amyloid precursor protein mRNAs following transient focal ischaemia. NeuroReport 7:2727-2731

47. Tanimukai H, Imaizumi K, Kudo T, Katayama T, Tsuda M, Takagi T, Tohyama M, Takeda M (1998) Alzheimer-associated presenilin-1 gene is induced in gerbil hippocampus after transient ischemia. Mol Brain Res 54:212-218

48. Pennypacker KR, Hernandez H, Benkovic S, Morgan DG, Willing AE, Sanberg PR (1999) Induction of presenilins in the rat brain after middle cerebral arterial occlusion. Brain Res Bull 48:539-543

49. Ali SM, Dunn E, Oostveen JA, Hall ED, Carter DB (1996) Induction of apolipoprotein E mRNA in the hippocampus of the gerbil after transient global ischemia. Mol Brain Res 38:37-44

50. Kamada H, Sato K, Zhang WR, Omori N, Nagano I, Shoji M, Abe K (2003) Spatiotemporal changes of apolipoprotein E immunoreactivity and apolipoprotein E mRNA expression after transient middle cerebral artery occlusion in rat brain. J Neurosci Res 73:545-556

51. Van Beek J, Chan P, Bernaudin M, Petit E, MacKenzie ET, Fontaine M (2000) Glial responses, clusterin, and complement in permanent focal cerebral ischemia in the mouse. Glia 31:39-50

52. Nalivaeva NN, Fisk L, Kochkina EG, Plesneva SA, Zhuravin IA, Babusikova E, Dobrota D, Turner AJ (2004) Effect of hypoxia/ ischemia and hypoxic preconditioning/reperfusion on expression of some amyloid-degrading enzymes. Ann NY Acad Sci 1035:21-33

53. Yan FL, Zhang J, Guan XN, Hong Z (2007) mRNA expression and activity of ADAM17 in hippocampus after chronic cerebral hypoperfusion: experiment with aged rats. Zhonghua Yi Xue Za Zhi 87:2515-2517

54. Pluta R, Furmaga-Jabłońska W, Maciejewski R, Ułamek-Kozioł M, Jabłoński M (2013) Brain ischemia activates $\beta$ - and $\gamma$ secretase cleavage of amyloid precursor protein: significance in sporadic Alzheimer's disease. Mol Neurobiol 47:425-434

55. Blasko I, Beer R, Bigl M, Apelt J, Franz G, Rudzki D, Ransmayr G, Kampfl A, Schliebs R (2004) Experimental traumatic brain injury in rats stimulates the expression, production and activity of Alzheimer's disease $\beta$-secretase (BACE-1). J Neural Transm 111:523-536

56. Chen XH, Siman R, Iwata A, Meaney DF, Trojanowski JQ, Smith DH (2004) Long-term accumulation of amyloid- $\beta, \beta$-secretase, presenilin-1, and caspase- 3 in damaged axons following brain trauma. Am J Pathol 165:357-371

57. Chuang CM, Hsieh CL, Lin HY, Lin JG (2008) Panax Notoginseng Burk attenuates impairment of learning and memory functions and increases ED1, BDNF and beta-secretase immunoreactive cells in chronic stage ischemia-reperfusion injured rats. Am J Chin Med 36:685-693

58. Wen Y, Onyewuchi O, Yang S, Liu R, Simpkins JW (2004a) Increased beta-secretase activity and expression in rats following transient cerebral ischemia. Brain Res 1009:1-8

59. Ye J, Pi R, Mao X, Chen X, Qin J, Xu S, Liu P (2009) Alterations in mRNA expression of BACE1, cathepsin B, and glutaminyl cyclase in mice ischemic brain. NeuroReport 20:1456-1460

60. Hebert SS, Bourdages V, Godin C, Ferland M, Carreau M, Levesque G (2003) Presenilin-1 interacts directly with the betasite amyloid protein precursor-cleaving enzyme (BACE1). Neurobiol Dis 13:238-245

61. Sastre M, Steiner H, Fuchs K, Capell A, Multhaup G, Condron MM, Teplow DB, Haass C (2001) Presenilin-dependent gammasecretase processing of beta-amyloid precursor protein at a site corresponding to the S3 cleavage of Notch. EMBO Rep 2:835-841

62. Wolfe MS, Xia W, Ostaszewski BL, Diehl TS, Kimberly WT, Selkoe DJ (1999) Two transmembrane aspartates in presenilin-1 required for presenilin endoproteolysis and gamma-secretase activity. Nature 398:513-517

63. Polavarapu R, An J, Zhang C, Yepes M (2008) Regulated intramembrane proteolysis of the low-density lipoprotein receptor-related protein mediates ischemic cell death. Am J Pathol 172:1355-1362

64. Pluta R, Januszewski S, Jabłoński M, Ułamek M (2010a) Factors in creepy delayed neuronal death in hippocampus following brain ischemia-reperfusion injury with long-term survival. Acta Neurochir Suppl 106:37-41 
65. Fujioka M, Taoka T, Matsuo Y, Mishima K, Ogoshi K, Kondo Y, Isuda M, Fujiwara M, Asano T, Sakaki T, Miyasaki A, Park D, Siesjo BK (2003) Magnetic resonance imaging shows delayed ischemic striatal neurodegeneration. Ann Neurol 54:732-747

66. Hall ED, Oostveen JA, Dunn E, Carter DB (1995) Increased amyloid protein precursor and apolipoprotein $\mathrm{E}$ immunoreactivity in the selectively vulnerable hippocampus following transient forebrain ischemia in gerbils. Exp Neurol 135:17-27

67. Ishimaru H, Ishikawa K, Haga S, Shoji M, Ohe Y, Haga C, Sasaki A, Takashashi A, Maruyama Y (1996a) Accumulation of apolipoprotein $\mathrm{E}$ and $\beta$-amyloid-like protein in a trace of the hippocampal CA1 pyramidal cell layer after ischaemic delayed neuronal death. NeuroReport 7:3063-3067

68. Jabłoński M, Maciejewski R, Januszewski S, Ułamek M, Pluta R (2011) One year follow up in ischemic brain injury and the role of Alzheimer factors. Physiol Res 60(suppl 1):S113-S119

69. Lin B, Schmidt-Kastner R, Busto R, Ginsberg MD (1999) Progressive parenchymal deposition of $\beta$-amyloid precursor protein in rat brain following global cerebral ischemia. Acta Neuropathol 97:359-368

70. Lin B, Ginsberg MD, Busto R (2001) Hyperglycemic but not normoglycemic global ischemia induces marked early intraneuronal expression of $\beta$-amyloid precursor protein. Brain Res 888:107-116

71. Pluta R, Barcikowska M, Dębicki G, Ryba M, Januszewski S (1997b) Changes in amyloid precursor protein and apolipoprotein $\mathrm{E}$ immunoreactivity following ischemic brain injury in rat with long-term survival: influence of idebenone treatment. Neurosci Lett 232:95-98

72. Pluta R, Barcikowska M, Mossakowski MJ, Zelman I (1998) Cerebral accumulation of beta-amyloid following ischemic brain injury with long-term survival. Acta Neurochir (Suppl) 71:206-208

73. Pluta R (2000b) No effect of anti-oxidative therapy on cerebral amyloidosis following ischemia-reperfusion brain injury. Folia Neuropathol 38:188-190

74. Pluta R, Jabłoński M (2012a) Alzheimer's factors in ischemic brain injury. In: Agrawal A (ed) Brain injury, pathogenesis, monitoring, recovery and management. InTech, Open Book, Croatia, pp $97-138$

75. Pluta R, Ułamek-Kozioł M, Januszewski S, Ściślewska M, Bogucka-Kocka A, Kocki J (2012) Alzheimer's factors in postischemic dementia. Rom J Morphol Embryol 53:461-466

76. Sinigaglia-Coimbra R, Cavalheiro EA, Coimbra CG (2002) Postischemic hypertermia induces Alzheimer-like pathology in the rat brain. Acta Neuropathol 103:444-452

77. Tomimoto H, Akiguchi I, Wakita H, Nakamura S, Kimura J (1995) Ultrastructural localization of amyloid protein precursor in the normal and postischemic gerbil brain. Brain Res 672:187-195

78. Yokota M, Saido TC, Tani E, Yamaura I, Minami N (1996) Cytotoxic fragment of amyloid precursor protein accumulates in hippocampus after global forebrain ischemia. J Cereb Blood Flow Metab 16:1219-1223

79. Badan I, Platt D, Kessler C, Popa-Wagner A (2003) Temporal dynamics of degenerative and regenerative events associated with cerebral ischemia in aged rats. Gerontology 49:356-365

80. Badan I, Dinca I, Buchhold B, Suofu Y, Walker L, Gratz M, Platt D, Kessler CH, Popa-Wagner A (2004) Accelerated accumulation of $\mathrm{N}$ - and $\mathrm{C}$-terminal beta APP fragments and delayed recovery of microtubule-associated protein $1 \mathrm{~B}$ expression following stroke in aged rats. Eur J Neurosci 19:2270-2280

81. Banati RB, Gehrmann J, Wießner C, Hossmann KA, Kreutzberg GW (1995) Glial expression of the $\beta$-amyloid precursor protein (APP) in global ischemia. J Cereb Blood Flow Metab 15:647-654
82. Nihashi T, Inao S, Kajita Y, Kawai T, Sugimoto T, Niwa M, Kabeya R, Hata N, Hayashi S, Yoshida J (2001) Expression and distribution of beta amyloid precursor protein and beta amyloid peptide in reactive astrocytes after transient middle cerebral artery occlusion. Acta Neurochir 143:287-295

83. Palacios G, Mengod G, Tortosa A, Ferrer I, Palacios JM (1995) Increased $\beta$-amyloid precursor protein expression in astrocytes in the gerbil hippocampus following ischaemia: association with proliferation of astrocytes. Eur J Neurosci 7:501-510

84. Takuma K, Baba A, Matsuda T (2004) Astrocyte apoptosis: implications for neuroprotection. Prog Neurobiol 72:111-127

85. Wyss-Coray T, Loike JD, Brionne TC, Lu E, Anankov R, Yan F, Silverstein SC, Husemann J (2003) Adult mouse astrocytes degrade amyloid-beta in vitro and in situ. Nat Med 9:453-457

86. Yam PS, Takasago T, Dewar D, Graham DI, McCulloch J (1997) Amyloid precursor protein accumulates in white matter at the margin of a focal ischaemic lesion. Brain Res 760:150-157

87. Pluta R (2002b) Glial expression of the beta-amyloid peptide in cardiac arrest. J Neurol Sci 203-204:277-280

88. Pluta R (2003) Blood-brain barrier dysfunction and amyloid precursor protein accumulation in microvascular compartment following ischemia-reperfusion brain injury with 1-year survival. Acta Neurochir (Suppl) 86:117-122

89. Pluta R (2005) Pathological opening of the blood-brain barrier to horseradish peroxidase and amyloid precursor protein following ischemia-reperfusion brain injury. Chemotherapy 51:223-226

90. Pluta R (2007a) Role of ischemic blood-brain barrier on amyloid plaques development in Alzheimer's disease brain. Curr Neurovasc Res 4:121-129

91. Oster-Granite ML, McPhie DL, Greenan J, Neve RL (1996) Agedependent neuronal and synaptic degeneration in mice transgenic for the $\mathrm{C}$ terminus of the amyloid precursor protein. J Neurosci 16:6732-6741

92. Cotter RL, Burke WJ, Thomas VS, Potter JF, Zheng J, Gendelman HE (1999) Insights into the neurodegenerative process of Alzheimer's disease: a role for mononuclear phagocyteassociated inflammation and neurotoxicity. J Leukoc Biol 65:416-427

93. Giulian D, Haverkamp LJ, Li J, Karshin WL, Yu J, Tom D, Li X, Kirkpatrick JB (1995) Senile plaques stimulate microglia to release a neurotoxin found in Alzheimer brain. Neurochem Int 27:119-137

94. Pluta R, Kocki J, Maciejewski R, Ułamek-Kozioł M, Jabłoński M, Bogucka-Kocka A, Czuczwar SJ (2012) Ischemia signaling to Alzheimer-related genes. Folia Neuropathol 50:322-329

95. Mattson MP, Zhu HY, Yu J, Kindy MS (2000) Presenilin-1 mutation increases neuronal vulnerability to focal ischemia in vivo and to hypoxia and glucose deprivation in cell culture: involvement of perturbed calcium homeostasis. J Neurosci 20:1358-1364

96. Yang Y, Kinney GA, Spain WJ, Breitner JCS, Cook DG (2004) Presenilin-1 and intracellular calcium stores regulate neuronal glutamate uptake. J Neurochem 88:1361-1372

97. Harris FM, Tesseur I, Brecht WJ, Xu O, Mullendorff K, Chang S, Wyss-Coray T, Mahley RW, Huang Y (2004) Asroglial regulation of apolipoprotein $\mathrm{E}$ expression in neuronal cells. Implications for Alzheimer's disease. J Biol Chem 279:3862-3868

98. Nishio M, Kohmura E, Yuguchi T, Nakajima Y, Fujinaka T, Akiyama C, Iwata A, Yoshimine T (2003) Neuronal apolipoprotein $\mathrm{E}$ is not synthesized in neuron after focal ischemia in rat brain. Neurol Res 25:390-394

99. Wiggins AK, Shen PJ, Gundlach AL (2003) Delayed, but prolonged increases in astrocytic clusterin (ApoJ) mRNA expression following acute cortical spreading depression in the rat: evidence for a role of clusterin in ischemic tolerance. Mol Brain Res 114:20-30 
100. Walton M, Young D, Sirimanne E, Dodd J, Christie D, Williams C, Gluckman P, Dragunow M (1996) Induction of clusterin in the immature brain following a hypoxic-ischemic injury. Mol Brain Res 39:137-152

101. Ishimaru H, Ishikawa K, Ohe Y, Takahashi A, Maruyama Y (1996b) Cystatin $\mathrm{C}$ and apolipoprotein $\mathrm{E}$ immunoreactivities in CA1 neurons in ischemic gerbil hippocampus. Brain Res 709:155-162

102. Ji ZS, Miranda RD, Newhouse YM, Weisgraber KH, Huang Y, Mahley RW (2002) Apolipoprotein E4 potentates amyloid $\beta$ peptide-induced lysosomal leakage and apoptosis in neuronal cells. J Biol Chem 277:21821-21828

103. Geddes JW, Schwab C, Craddock S, Wilson JL, Pettigrew LC (1994) Alterations in tau immunostaining in the rat hippocampus following transient cerebral ischemia. J Cereb Blood Flow Metab $14: 554-564$

104. Dewar D, Graham DI, Teasdale GM, McCulloch J (1993) Alz-50 and ubiquitin immunoreactivity is induced by permanent focal cerebral ischaemia in the cat. Acta Neuropathol 86:623-629

105. Dewar D, Graham DI, Teasdale GM, McCulloch J (1994) Cerebral ischemia induces alterations in tau and ubiquitin proteins. Dementia 5:168-173

106. Dewar D, Dawson D (1995) Tau protein is altered by focal cerebral ischaemia in the rat: an immunohistochemical and immunoblotting study. Brain Res 684:70-78

107. Irving EA, Yatsushiro K, McCulloch J, Dewar D (1997) Rapid alteration of tau in oligodendrocytes after focal ischemic injury in the rat: involvement of free radicals. J Cereb Blood Flow Metab $17: 612-622$

108. Uchihara T, Nakamura A, Arai T, Ikeda K, Tsuchiya K (2004) Microglial tau undergoes phosphorylation-independent modification after ischemia. Glia 45:180-187

109. Stamer K, Vogel R, Thies E, Mandelkow E, Mandelkow EM (2002) Tau blocks traffic of organelles, neurofilaments, and APP vesicles in neurons and enhances oxidative stress. J Cell Biol 156:1051-1063

110. Wen Y, Yang S, Liu R, Simpkins JW (2004b) Transient cerebral ischemia induces site-specific hyperphosphorylation of tau protein. Brain Res 1022:30-38

111. Wen Y, Yang S, Liu R, Brun-Zinkernagel AM, Koulen P, Simpkins JW (2004) Transient cerebral ischemia induces aberrant neuronal cell cycle re-entry and Alzheimer's disease-like tauopathy in female rats. J Biol Chem 279:22684-22692

112. Kitamura Y, Ishida Y, Takata K, Kakimura J, Mizutani H, Shimohama S, Akaike A, Taniguchi T (2001) Alpha-synuclein protein is not scavenged in neuronal loss induced by kainic acid or focal ischemia. Brain Res 898:181-185

113. Goedert M (2001) Alpha-synuclein and neurodegenerative diseases. Nat Rev Neurosci 2:492-501

114. Hashimoto M, Masliah E (1999) Alpha-synuclein in Lewy body disease and Alzheimer's disease. Brain Pathol 9:707-720

115. Wisniewski T, Frangione B (1992) Apolipoprotein E: a pathological chaperone protein in patients with cerebral and systemic amyloid. Neurosci Lett 135:235-238

116. Block F (1999) Global ischemia and behavioural deficits. Prog Neurobiol 58:279-295

117. Popa-Wagner A (2007) Alzheimer's disease pathological factors in ischemic aged brain. In: Pluta R (ed) Ischemia-reperfusion pathways in Alzheimer's disease. Nova Science Publishers, Inc, New York, pp 51-84

118. Yang SH, Simpkins JW (2007) Ischemia-reperfusion promotes tau and beta-amyloid pathology and a progressive cognitive impairment. In: Pluta R (ed) Ischemia-reperfusion pathways in Alzheimer's disease. Nova Science Publishers Inc, New York, pp 113-138

119. Karasawa Y, Araki H, Otomo S (1994) Changes in locomotor activity and passive avoidance task performance induced by cerebral ischemia in mongolian gerbils. Stroke 25:645-650
120. Kuroiwa T, Bonnekoh P, Hossmann KA (1991) Locomotor hyperactivity and hippocampal CA1 injury after transient forebrain ischemia in gerbils. Neurosci Lett 122:141-144

121. Langdon KD, Granter-Button S, Corbett D (2008) Persistent behavioral impairments and neuroinflammation following global ischemia in the rat. Eur J Neurosci 28:2310-2318

122. Colbourne F, Corbett D (1995) Delayed postischemic hypothermia: a six month survival study using behavioral and histological assessments of neuroprotection. J Neurosci 15:7250-7260

123. Mileson BE, Schwartz RD (1991) The use of locomotor activity as a behavioral screen for neuronal damage following transient forebrain ischemia in gerbils. Neurosci Lett 128:71-76

124. Davis HP, Tribuna J, Pulsinelli WA, Volpe BT (1986) Reference and working memory of rats following hippocampal damage induced by transient forebrain ischemia. Physiol Behav 37:387-392

125. Kiyota Y, Miyamoto M, Nagaoka A (1991) Relationship between brain damage and memory impairment in rats exposed to transient forebrain ischemia. Brain Res 538:295-302

126. Block F, Schwarz M (1998) Global ischemic neuronal damage relates to behavioural deficits: a pharmacological approach. Neuroscience 82:791-803

127. Karhunen H, Pitkanen A, Virtanen T, Gureviciene I, Pussinen R, Ylinen A, Sivenius J, Nissinen J, Jolkkonen J (2003) Long-term functional consequences of transient occlusion of the middle cerebral artery in rats: a 1-year follow-up of the development of epileptogenesis and memory impairment in relation to sensorimotor deficits. Epilepsy Res 54:1-10

128. Roof RL, Schielke GP, Ren X, Hall ED (2001) A comparison of longterm functional outcome after 2 middle cerebral artery occlusion models in rats. Stroke 32:2648-2657

129. Ishibashi S, Kuroiwa T, LiYuan S, Katsumata N, Li S, Endo S, Mizusawa H (2006) Long-term cognitive and neuropsychological symptoms after global cerebral ischemia in Mongolian gerbils. Acta Neurochir (Suppl) 96:299-302

130. Hossmann KA, Schmidt-Kastner R, Grosse Ophoff B (1987) Recovery of integrative central nervous function after one hour global cerebro-circulatory arrest in normothermic cat. J Neurol Sci 77:305-320

131. Flynn RWV, MacWalter RSM, Doney ASF (2008) The cost of cerebral ischemia. Neuropharmacology 55:250-256

132. Jellinger KA (2007) The enigma of vascular cognitive disorder and vascular dementia. Acta Neuropathol 113:349-388

133. Fillit H, Hill J (2002) The costs of vascular dementia: a comparison with Alzheimer's disease. J Neurol Sci 203-204:35-39

134. Leys D, Englund E, Erkinjuntti T (2002) Vascular dementia. In: Qizilbash N, Schneider LS, Chui H (eds) Evidence-based dementia practice. Blackwell, Oxford

135. Bornstein NM, Gur AY, Treves TA, Reider-Groswasser I, Aronovich BD, Klimovitzky SS, Varssano D, Korczyn AD (1996) Do silent brain infarctions predict the development of dementia after first ischemic stroke? Stroke 27:904-905

136. Madureira S, Guerreiro M, Ferro JM (2001) Dementia and cognitive impairment three months after stroke. Eur J Neurol $8: 621-627$

137. Pohjasvaara T, Erkinjuntti T, Ylikoski R, Hietanen M, Vataja R, Kaste M (1998) Clinical determinants of poststroke dementia. Stroke 29:75-81

138. Tatemichi TK, Desmond DW, Mayeux R, Paik M, Stern Y, Sano M, Remien RH, Williams JB, Mohr JP, Hauser WA et al (1992) Dementia after stroke: baseline frequency, risks, and clinical features in a hospitalized cohort. Neurology 42:1185-1193

139. Loeb C, Gandolfo C, Croce R, Conti M (1992) Dementia associated with lacunar infarction. Stroke 23:1225-1229

140. Tatemichi TK, Foulkes MA, Mohr JP, Hewitt JR, Hier DB, Price TR, Wolf PA (1990) Dementia in stroke survivors in the Stroke 
Data Bank cohort: prevalence, incidence, risk factors and computed tomographic findings. Stroke 21:858-866

141. Henon H, Durieu I, Guerouaou D, Lebert F, Pasquier F, Leys D (2001) Poststroke dementia: incidence and relationship to prestroke cognitive decline. Neurology 57:1216-1222

142. Altieri M, Di Piero V, Pasquini M, Gasparini M, Vanacore N, Vicenzini E, Lenzi GL (2004) Delayed poststroke dementia: a 4year follow-up study. Neurology 62:2193-2197

143. Kokmen E, Whisnant JP, O'Fallon WM, Chu CP, Beard CM (1996) Dementia after ischemic stroke: a population-based study in Rochester, Minnesota (1960-1984). Neurology 46:154-159

144. Desmond DW, Moroney JT, Sano M, Stern Y (2002) Incidence of dementia after ischemic stroke: results of a longitudinal study. Stroke 33:2254-2260

145. Samuelsson M, Soderfeldt B, Olsson GB (1996) Functional outcome in patients with lacunar infarction. Stroke 27:842-846

146. Fonte J, Miklossy J, Atwood C, Martins R (2001) The severity of cortical Alzheimer's type changes is positively correlated with increased amyloid- $\beta$ levels: resolubilization of amyloid- $\beta$ with transition metal ion chelators. J Alzheimers Dis 3:209-219

147. Klunk WE, Engler H, Nordberg A, Wang Y, Blomqvist G, Holt DP, Bergstrom M, Savitchera I, Huang GF, Estrada S, Ausen B, Debnath ML, Barletta J, Price JC, Sandell J, Lopresti BJ, Wall A, Koivisto P, Antoni G, Mathis CA, Langstrom B (2004) Imaging brain amyloid in Alzheimer's disease with Pittsburgh CompoundB. Ann Neurol 55:306-319

148. Lue LF, Kuo YM, Roher AE, Brachova L, Shen Y, Sue L, Beach T, Kurth JH, Rydel RE, Rogers J (1999) Soluble amyloid $\beta$ peptide concentration as a predictor of synaptic change in Alzheimer's disease. Am J Pathol 155:853-862

149. Hyman BT, Marzloff K, Arriagada PV (1993) The lack of accumulation of senile plaques or amyloid burden in Alzheimer's disease suggests a dynamic balance between amyloid deposition and resolution. J Neuropathol Exp Neurol 52:594-600

150. Gomez-Isla T, Hollister R, West H, Mui S, Growdon JH, Peterson RC, Parisi JE, Hyman BT (1997) Neuronal loss correlates with but exceeds neurofibrillary tangles in Alzheimer's disease. Ann Neurol 41:17-24

151. Kienlen-Campard P, Miolet S, Tasiaux B, Octave JN (2002) Intracellular amyloid-beta 1-42, but not extracellular soluble amyloid-beta peptides, induces neuronal apoptosis. J Biol Chem 277:15666-15670

152. Meyer-Luehmann M, Stalder M, Herzig MC, Kaeser SA, Kohler E, Pfeifer M, Boncristiano S, Mathews PM, Mercken M, Abramowski D, Staufenbiel M, Jucker M (2003) Extracellular amyloid formation and associated pathology in neural grafts. Nat Neurosci 6:370-377

153. Selkoe DJ (2002) Alzheimer's disease is a synaptic failure. Science 298:789-791

154. Andorfer C, Acker CM, Kress Y, Hof PR, Duff K, Davies P (2005) Cell-cycle reentry and cell death in transgenic mice expressing nonmutant human tau isoforms. J Neurosci 25:5446-5454

155. Armstrong RA (2006) Plaques and tangles and the pathogenesis of Alzheimer's disease. Folia Neuropathol 44:1-11

156. Armstrong RA (2011) Spatial patterns of $\beta$-amyloid $(A \beta)$ deposits in familial and sporadic Alzheimer's disease. Folia Neuropathol 49:153-161

157. Games D, Adams D, Alessandrini R, Barbour R, Berthelette P, Blackwell C, Carr T, Clements J, Donaldson T, Gillespie F, Guido T, Hagopian S, Johnson-Wood K, Khan K, Lee M, Leibowitz P, Lieberburg I, Little S, Masliah E, McConlogue L, MontoyaZavala M, Mucke L, Paganini L, Penniman E, Power M, Schenk D, Seubert P, Snyder B, Soriano F, Tan H, Vitale J, Wadsworth S, Wolozin B, Zhao J (1995) Alzheimer-type neuropathology in transgenic mice overexpressing V717F beta-amyloid precursor protein. Nature 373:523-527
158. Pluta R, Lossinsky AS, Wiśniewski HM, Mossakowski MJ (1994a) Early blood-brain barrier changes in the rat following transient complete cerebral ischemia induced by cardiac arrest. Brain Res 633:41-52

159. Pluta R, Lossinsky AS, Walski M, Wiśniewski HM, Mossakowski MJ (1994) Platelet occlusion phenomenon after short- and longterm survival following complete cerebral ischemia in rats produced by cardiac arrest. J Brain Res 35:463-471

160. Pluta R, Barcikowska M, Januszewski S, Misicka A, Lipkowski AW (1996) Evidence of blood-brain barrier permeability/leakage for circulating human Alzheimer's $\beta$-amyloid-(1-42)-peptide. NeuroReport 7:1261-1265

161. Miyakawa T, Kimura T, Hirata S, Fujise N, Ono T, Ishizuka K, Nakabayashi J (2000) Role of blood vessels in producing pathological changes in the brain with Alzheimer's disease. Ann NY Acad Sci 903:46-54

162. Miyakawa T (2002) Vascular pathology in Alzheimer's disease. Ann NY Acad Sci 977:303-305

163. Fukuchi K, Ho L, Younkin SG, Kunkel DD, Ogburn CE, LeBoeuf RC, Furlong CE, Deeb SS, Nochlin D, Wegiel J, Wisniewski HM, Martin GM (1996) High levels of circulating beta-amyloid peptide do not cause cerebral beta-amyloidosis in transgenic mice. Am J Pathol 149:219-227

164. Seubert P, Vigo-Pelfrey C, Esch F, Lee M, Dovey H, Davis D, Sinhas S, Schlossmacher M, Swindlehurst C, McCormack R, Wolfertt R, Selkoe D, Liberburg I, Schenk D (1992) Isolation and quantification of soluble Alzheimer's $\beta$-peptide from biological fluids. Nature 359:325-327

165. Scholz W (1938) Studien zur Pathologie der Hirngefasse in Senium. In: Proceedings of the Fifth International Congress of Neuropathology, Zurich 490-494

166. Pluta R, Misicka A, Januszewski S, Barcikowska M, Lipkowski AW (1997) Transport of human $\beta$-amyloid peptide through the rat blood-brain barrier after global cerebral ischemia. Acta Neurochir (Suppl) 70:247-249

167. Pluta R, Barcikowska M, Misicka A, Lipkowski AW, Spisacka S, Januszewski S (1999) Ischemic rats as a model in the study of the neurobiological role of human $\beta$-amyloid peptide. Time-dependent disappearing diffuse amyloid plaques in brain. NeuroReport 10:3615-3619

168. Pluta R, Misicka A, Barcikowska M, Spisacka S, Lipkowski AW, Januszewski S (2000) Possible reverse transport of $\beta$-amyloid peptide across the blood-brain barrier. Acta Neurochir (Suppl) 76:73-77

169. Pluta R, Ułamek M (2008a) New proposals for treatment sporadic Alzheimer's disease. Cent Nerv Syst Agents Med Chem 8:286-296

170. Pluta R, Ułamek M (2008b) Brain ischemia and ischemic bloodbrain barrier as etiological factors in sporadic Alzheimer's disease. Neuropsychiatr Dis Treat 4:855-864

171. Koistinaho M, Kettunen MI, Goldsteins G, Keinanen R, Salminen A, Ort M, Bures J, Liu D, Kauppinen RA, Higgins LS, Koistinaho J (2002) $\beta$-Amyloid precursor protein transgenic mice that harbor diffuse $A \beta$ deposits but do not form plaques show increased ischemic vulnerability: role of inflammation. Proc Natl Acad Sci USA 99:1610-1615

172. Sheng B, Cheng LF, Law CB, Li HL, Yeung KM, Lau KK (2007) Coexisting cerebral infarction in Alzheimer's disease is associated with fast dementia progression: applying the National Institute for Neurological Disorders and Stroke/Association Internationale pour la Recherche et l'Enseignement en Neurosciences Neuroimaging Criteria in Alzheimer's disease with Concomitant Cerebral Infarction. J Am Geriatr Soc 55:918-922

173. Snowdon DA, Greiner LH, Mortimer JA, Riley KP, Greiner PA, Markesbery WR (1997) Brain infarction and the clinical expression of Alzheimer disease. The nun study. JAMA 277:813-817 
174. Schmitz C, Rutten BP, Pielen A, Schafer S, Wirths O, Tremp G, Czech C, Blanchard V, Multhaup G, Rezaie P, Korr H, Steinbusch HW, Pradier L, Bayer TA (2004) Hippocampal neuronal loss exceeds amyloid plaque load in a transgenic mouse model of Alzheimer's disease. Am J Pathol 164:1495-1502

175. Hiltunen M, Van Groen T, Jolkkonen J (2009) Functional roles of amyloid- $\beta$ protein precursor and amyloid- $\beta$ peptides: evidence from experimental studies. J Alzheimers Dis 18:401-412

176. Dietrich WD, Kraydieh S, Prado R, Stagliano NE (1998) White matter alterations following thromboembolic stroke: a $\beta$-amyloid precursor protein immunocytochemical study in rats. Acta Neuropathol 95:524-531

177. Van Groen T, Puurunen K, Maki HM, Sivenius J, Jolkkonen J (2005) Transformation of diffuse beta-amyloid precursor protein and beta-amyloid deposits to plaques in the thalamus after transient occlusion of the middle cerebral artery in rats. Stroke 36:1551-1556

178. Ginsberg SD, Crino PB, Hemby SE, Weingarten JA, Lee VMY, Eberwine JH, Trojanowski JQ (1999) Predominance of neuronal mRNAs in individual Alzheimer's disease senile plaques. Ann Neurol 45:174-181

179. Duyckaerts C (2004) Looking for the link between plaques and tangles. Neurobiol Aging 25:735-739
180. Perez M, Cuadros R, Benitez MJ, Jimenez JS (2004) Interaction of Alzheimer's disease A $\beta$ peptide 25-35 with tau protein and with a tau peptide containing the microtubule-binding domain. $\mathrm{J}$ Alzheimers Dis 6:461-470

181. Pluta R (2007b) Is the ischemic blood-brain barrier a Trojan horse in Alzheimer's disease brain? In: Pluta R (ed) Ischemiareperfusion pathways in Alzheimer's disease. Nova Science Publishers, Inc, New York, pp 139-184

182. Etiene D, Kraft J, Ganju N, Gomez-Isla T, Gemelli B, Hyman BT, Hedley-Whyte ET, Wands JR, De La Monte SM (1998) Cerebrovascular pathology contributes to the heterogeneity of Alzheimer's disease. J Alzheimers Dis 1:119-134

183. Kudo T, Imaizumu K, Tanimukai H, Katayama T, Sato N, Nakamura Y, Tanaka T, Kashiwagi Y, Jinno Y, Tohyama M, Takeda M (2000) Are cerebrovascular factors involved in Alzheimer's disease? Neurobiol Aging 21:215-224

184. Grammas P, Moore P, Weigel PH (1999) Microvessels from Alzheimer's disease brains kill neurons in vitro. Am J Pathol 154:337-342

185. Kato T, Hirano A, Katagiri T, Sasaki H, Yamada S (1988) Neurofibrillary tangle formation in the nucleus basalis of Meynert ipsilateral to a massive cerebral infarct. Ann Neurol 23:620-623 